\title{
HUBUNGAN ANTARA DUKUNGAN SOSIAL KELUARGA DENGAN SUCCESSFUL AGING PADA LANSIA DI RW O6 DESA BULU KECAMATAN AGROMULYO SALATIGA
}

\author{
Wayan Nandia Sari', Christiana Hari Soetjiningsih ${ }^{2}$ \\ Email:wayannandia09@gmail.com ${ }^{1}$ \\ Universitas Kristen Satya Wacana ${ }^{1,2}$
}

\begin{abstract}
This study aims to determine whether or not there is a relationship between family social support and successful aging in the elderly. Successful aging is meant to achieve success in old age with one of the factors being family social support. The subjects of this study were elderly aged between 60-85 years in RW 06 Desa Bulu kec. Argomulyo Salatiga. Data use taken quantitative method with a sample model of saturated and sampling nonprobability sampling. Based on the results of the study the results of correlation coefficient $(r)$ $=0.042 ; p<0.05$ with the influence of social support on successful aging at $4.8 \%$ and $95.2 \%$ influenced by other factors. The researcher concluded that there was a positive relationship between social support and successful aging in the elderly in RW 06 Desa Bulu Kec. Argomulyo Salatiga.
\end{abstract}

Keywords: Family Social Support; Successful aging

Abstrak
Penelitian ini bertujuan untuk mengetahui ada atau tidaknya hubungan dukungan sosial keluarga dengan successful aging pada lansia. Successful aging yang dimaksudkan adalah pencapaian keberhasilan di masa tua dengan salah satu faktornya adalah dukungan sosial keluarga. Subjek penelitian ini adalah lansia berusia antara 60-85 tahun di RW 06 desa bulu kec. Argomulyo Salatiga. data diambil menggubakan metode kuantitatif dengan model sampel jenuh serta pengambilan sampel nonprobability sampling. Berdasarkan hasil penelitian didapatkan hasil koefesien korelasi $(\mathrm{r})=0,042 ; \mathrm{p}<0,05$ dengan pengaruh dukungan sosial terhadap successful aging sebesar $4.8 \%$ dan $95.2 \%$ dipengaruhi oleh faktor lain. Peneliti menyimpulkan bahwa terdapat hubungan positif antara dukungan sosial dengan successful aging pada lansia di RW 06 Desa Bulu kec. Argomulyo Salatiga.

Kata kunci: Dukungan Sosial Keluarga; Successful aging

\section{PENDAHULUAN}

Lansia merupakan proses akhir dari masa perkembangan hidup manusia. Tahap terakhir dari rentan kehidupan manusia dapat dibagi menjadi dua, yaitu masa usia lanjut dini, yang kisar antara usia enam puluh tahun sampai tujuh puluh tahun, dan usia lanjut yang dimulai pada usia tujuh puluh sampai akhir kehidupan. Periode pada rentan kehidupan yang ditandai dengan penurunan fungsi-fungsi fisik, biasanya diasosiasikan dengan proses penuaan, dimulai pada usia yang berbeda antar individu (Hurlock, 1980).
Pengaruh perubahan fisik pada masa usia lajut digolongkan dalam bahaya psikologis. Hilangnya daya Tarik dan penampilan seksual yang tepat mungkin melibatkan pria atau wanita merasa ditolak oleh kelompok sosial. Hilangnya pendengaran mengganggu mereka dalam berkomunikasi dengan orang lain. Banyak lansia yang kesulitan bicara karena giginya ompong atau gigi palsunya tidak cocok lagi. Ini juga merupakan salah satu bukti yang dapat menghambat komunikasi dan hubungan sosial (Hurlock 1980). 
Selain perubahan fisik, lansia juga mengalami perubahan kepribadian. Berbagai gangguan kepribadian pada tingkat yang lebih serius seperti penyakit mental, meningkat dengan bertambahnya usia. Pada usia enampuluhan terjadi gangguan gangguan seperti psikosa dengan kerusakan syaraf otak dan penderitaan kepikunan karena kehilangan kapasitas intelektual dan integritas kepribadian. Gangguan-gangguan ini meningkat secara konstan sampai akhir hayat dan setelah usia tujuh puluh tahun, lebih sering terjadi kepikunan (Hurlock 1980).

Dengan perubahan-perubahan tersebut, tidak dapat dijadikan alasan untuk tidak bahagia. Secara umum, lansia yang bahagia lebih sadar dan siap untuk terikat dengan kegiatan baru dibanding lansia yang merasa tidak bahagia (Hurlock 1980). Diterima oleh dan memperoleh respek dari kelompok sosial, menerima kenyatan diri dan kondisi hidup yang ada sekarang, walaupun kenyataan tersebut berada dibawah kondisi yang diharapkan, dan menikmati kegiatan sosial yang dilakukan dengan kerabat keluarga dan teman-teman merupakan kondisi penting yang menunjang kebahagiaan pada masa lanjut usia (Hurlock 1980).

Lansia dianggap bahagia dan sukses di usia tua apabila terhindar dari penyakit atau keterbatasan yang berkaitan dengan penyakit, mempertahankan fungsi fisik dan kondisi yang tinggi, dan mempertahankan keterlibatan sosial yang aktif dan aktivitas yang produktif (Rowe \& Khan, 1997). Seseorang cenderung hidup lebih lama jika mereka memiliki perasaan kontrol mengenai peran seperti pasangan, orang tua, pemberian nafkah, atau teman yang dianggap penting bagi mereka.

Penuaan suskes bergantung pada sistem nilai tidak bisa dihindari. Menurut para pengkritik, istilah ini maka akan menjadi beban dan bukan membebaskan lansia dengan menempatkan tekanan pada lansia untuk memenuhi standar yang tidak ingin atau tidak bisa mereka penuhi (Holstein \& Minkler 2003).

Fenomena successful aging pada lansia yang ada di RW 06 desa Bulu, kec. Argomulyo Salatiga, berdasarkan hasil observasi dan wawancara yang penulis lakukan yaitu, masih banyak lansia yang mengemis didepan pertokoan, hidup dengan memisahkan diri dari anak dan cucu. Selain itu ada beberapa lansia yang sengaja ditinggalkan oleh keluarganya begitu saja, sehingga dalam kesehariannya bergantung pada orang lain yang bukan keluarganya. Hal ini dikarenakan kurangnya dukungan dari keluarga dan lingkungan sekitar. Banyaknya tekanan 
yang dialami oleh lansia menyebabkan beberapa lansia mudah terserang penyakit. Dukungan dari keluarga dan lingkungan dapat mempertahankan fungsi fisik dan fungsi kognitif dengan baik, selain itu keterlibatan lansia dalam aktivitas sosial maupun kerohanian dapat meningkatkan kesejahteraan pada lansia. Tanpa adanya dukungan dari keluarga dan lingkungan dapat menghambat kesejahteraan lansia.

Faktor yang mempengaruhi successful aging menurut Budiatri (2010) yaitu faktor fisik dan kesehatan, faktor aktivitas, faktor psikologis, faktor sosial dan faktor religiusitas. Sedangkan menurut Sudirman (2011) faktor-faktor yang mempengaruhi successful aging adalah mobilitas fisik, pendidikan, pekerjaan, dan aktivtas. Selain itu menurut Rowe dan Khan (1997) gaya hidup sangat berperan dalam pemeliharaan kesehatan bagi lansia itu sendiri. Dukungan sosial juga sebagai faktor yang memengaruhi successful aging. Menurut (Santrock, 2012) dukungan sosial dapat membantu individu di semua usia untuk mengatasi masalah secara lebih efektif. Bagi lansia dukungan sosial dapat meningkatkan ketahanan fisik dan mental.

Penelitian dari Laura Odell Howie (2014) harapan hidup lansia jauh lebih lama karena adanya dukungan dari keluarga dan lingkungannya, selain itu adanya pengawasan kegiatan hidup seharihari (ADL) juga dapat memperpanjang usia harapan hidup lansia. Hasil penelitian dari Geizy Azhari Putri (2015) melaporkan bahwa success atau unsuccess-nya lansia berkaitan dengan dukungan sosial yang diterima oleh lansia tersebut. Semakin banyak lansia menerima dukungan sosial dari keluarga maupun lingkungan maka akan semakin success, sedangkan semakin sedikit lansia menerima dukungan sosial maka semakin unsuccess lansia tersebut. Kemudian diteliti lagi oleh Susi Astriani Br. Ginting (2017) didapatkan hasil $50,5 \%$ atau sebanyak 47 dari 93 lansia yang mencapai successful aging. Selain itu ada hubungan atara dukungan sosial dengan successful aging pada lanjut usia. Sebaliknya penelitian dilakukan oleh Meta Amelia W.S dan Endang Sri Indrawati (2011) menyatakan bahwa terdapat hubungan negative yang signifikan antara dukungan sosial dengan depresi pada lansia di panti wreda Wening Waroyo Jawa Tengah efektifitas regresi sebesar 0,237 artinya depresi $23,7 \%$ ditentukan oleh dukungan sosial.

Berdasarkan hal tersebut, peneliti ingin meneliti tentang hubungan antara dukungan sosial sengan successful aging pada lansia khususnya di Desa Bulu kec. Argomulyo Salatiga, karena saat ini 
penelitian mengenai successful aging dan dukungan sosial belum ada di kota ini. Dari uraian latar belakang, peneliti ingin mengetahui apakah ada hubungan antara dukungan sosial keluarga dengan successful aging pada lansia di Salatiga Penelitian ini bertujuan untuk mengetahui adakah hubungan antara dukungan sosial dengan successful aging pada lansia di Salatiga.

\section{METODE PENELITIAN}

Partisipan penelitian diambil dari populasi lansia di RW 06 Desa Bulu Kecamatan Argomulyo Salatiga berjumlah 63 lansia dengan usia antara 60-85 tahun, terdiri dari 30 lansia berjenis kelamin perempuan dan 33 berjenis kelamin laki-laki. Teknik pengambilan sampel yang digunakan pada penelitian ini yaitu sample jenuh. Penelitian ini menggunakan metode kuantitatif dengan teknik pengumpulan data berupa skala psikologi, terdiri dari skala successful aging yang berjumlah 12 aitem dan skala dukungan sosial yang berjumlah 13 . Penelitian ini menggunakan metode kuantitatif dengan model sampel jenuh serta pengambilan sampel non probability sampling. Analisis data dengan teknik statistik yang digunakan untuk mengolah data yang diperoleh akan menggunakan program Software Statistik pada komputer (IBM SPSS Statistics 23).
HASIL DAN PEMBAHASAN

Analisis Deskriptif Dukungan Sosial

Tabel 1. Kategorisasi Skor Variabel Dukungan Sosial

\begin{tabular}{|l|l|l|l|l|}
\hline Kategori & Interval & Frekuensi & Presentase & Mean \\
\hline Sanggat rendah & $13 \leq x<20.8$ & 0 & 0 & \\
\hline Rendah & $20.8 \leq x<28.6$ & 0 & 0 & \\
\hline Sedang & $28.6 \leq x<36.4$ & 6 & $9.52 \%$ & \\
\hline Tinggi & $36.4 \leq x<44.2$ & 51 & $80.96 \%$ & 40.34 \\
\hline Sangat tinggi & $44.2 \leq x<52$ & 6 & $9.52 \%$ & \\
\hline Jumlah & & 63 & $100 \%$ & \\
\hline
\end{tabular}

Pada tabel 1 kategori skor variable dukungan sosial dari sejumlah 63 subjek menunjukan tingkat penyebaran kategori dari sangat rendah hingga sangat tinggi. Dapat dilihat bahwa pada kategori "tinggi" didapat persentase sebesar $80.96 \%$, pada kategori "Sangat Tinggi" didapat persentase sebesar $9.52 \%$, dan pada kategori "Sedang" didapat persentase 9.52\%. Dari tabel di atas juga dapat di lihat bahwa mean/rata-rata sebesar 40.34 yang berada pada kategori "Tinggi".

\section{Successful aging}

Tabel 2 Kategorisasi Successful aging

\begin{tabular}{|l|l|l|l|l|}
\hline Kategori & Interval & Frekuensi & Presentase & Mean \\
\hline Sangat rendah & $12 \leq x<19.3$ & 0 & 0 & \\
\hline Rendah & $19.3 \leq x<26.5$ & 0 & 0 & \\
\hline Sedang & $26.5 \leq x<33.7$ & 27 & $42.86 \%$ & \\
\hline Tinggi & $33.7 \leq x<40.9$ & 26 & $41.27 \%$ & 35.21 \\
\hline Sangat tinggi & $40.9 \leq x<48$ & 10 & $15.87 \%$ & \\
\hline & & 63 & $100 \%$ & \\
\hline
\end{tabular}

Pada tabel 2, kategorisasi skor variabel successful aging dari sejumlah 63 
subjek menunjukkan tingkat penyebaran kategori dari sangat rendah hingga sangat tinggi. Dapat dilihat bahwa pada variabel successful aging, sebanyak 27 lansia (42.86\%) berada pada kategori "Sedang", 26 lansia $(41,27 \%)$ berada pada kategori "Tinggi", dan 6 lansia (15.87\%) berada pada kategori "Sangat Tinggi". Dari tabel di atas juga dapat di lihat bahwa mean/rata-rata lansia (35.20) berada pada kategori "Tinggi".

\section{Uji Normalitas}

Tabel 3. Normalitas Skala Dukungan Sosial dan Successful Aging

One-Sample Kolmogorov-Smirnov Test

\begin{tabular}{llr|r} 
& & \multicolumn{1}{c|}{ SA } & \multicolumn{1}{c}{ Duksos } \\
\hline $\mathrm{N}$ & & 63 & 63 \\
\hline $\begin{array}{l}\text { Normal } \\
\text { Parameters }\end{array}$ & Mean & 35.2063 & 40.3492 \\
\cline { 2 - 4 } & $\begin{array}{l}\text { Std. } \\
\text { Deviation }\end{array}$ & 4.65991 & 3.14775 \\
\hline $\begin{array}{l}\text { Most Extreme } \\
\text { Differences }\end{array}$ & Absolute & .210 & .195 \\
\cline { 2 - 4 } & Positive & .210 & .195 \\
\cline { 2 - 4 } & Negative & -.091 & -.084 \\
\hline Test Statistic & & .210 & .195 \\
\hline Asymp. Sig. (2-tailed) & $.000^{\mathrm{c}}$ & $.000^{\mathrm{c}}$ \\
\hline
\end{tabular}

Uji normalitas menggunakan uji Kolmogrov-Smirnov yang menunjukan variabel dukungan sosial memiliki nilai K-S-Z sebesar 0.195 dengan signifikansi sebesar 0.00 ( $>>0.05)$. pada variabel successful aging memiliki nilai K-S-Z sebesar 0.210 dengan signifikansi 0.00 (p> 0.05). Dengan demikian dapat disimpulkan bahwa variabel dukungan sosial dan successful aging sama-sama berdistribusi tidak normal

\section{Uji Linearitas}

Tabel 4. Linearitas Skala Dukungan Sosial Dan Successful Aging

\begin{tabular}{|c|c|c|c|c|c|c|c|}
\hline & & & VA Tab & & & & \\
\hline & & & $\begin{array}{l}\text { Sum of } \\
\text { Squares }\end{array}$ & df & $\begin{array}{l}\text { Mean } \\
\text { Square }\end{array}$ & $\mathrm{F}$ & Sig. \\
\hline $\begin{array}{l}\text { SA* } \\
\text { Duksos }\end{array}$ & $\begin{array}{l}\text { Between } \\
\text { Groups }\end{array}$ & (Combined) & 310.088 & 12 & 25.841 & 1.247 & .279 \\
\hline & & Linearity & 38.837 & 1 & 38.837 & 1.874 & .117 \\
\hline & & $\begin{array}{l}\text { Deviation from } \\
\text { Linearity }\end{array}$ & 271.251 & 11 & 24.659 & 1.190 & .318 \\
\hline & Within G & & 1036.229 & 50 & 20.725 & & \\
\hline & Total & & 1346.317 & 62 & & & \\
\hline
\end{tabular}

Dari hasil uji linearitas tabel 4 diperoleh nilai $\mathrm{F}$ beda sebesar 1.190 dengan sig 0.318 (p> 0,05) yang menunjukan terdapat hubungan linear antara variabel dukungan sosial dengan successful aging

\section{Uji Korelasi}

Berdasarkan uji asumsi yang telah dilakukan, diketahui bahwa data tidak berdistribusi normal dan variabel-variabel penelitian linear. Sehingga uji korelasi yang digunakan dalam penelitian ini adalah korelasi Spearman's Rho

Tabel 5. Korelasi Antara Dukungan Sosial Dengan Successful aging 
Correlations

\begin{tabular}{|c|c|c|c|c|}
\hline & & & SA & Duksos \\
\hline \multirow{6}{*}{$\begin{array}{l}\text { Spearman's } \\
\text { rho }\end{array}$} & \multirow[t]{3}{*}{ SA } & Correlation Coefficient & 1.000 & $.219^{*}$ \\
\hline & & Sig. (1-tailed) & . & .042 \\
\hline & & $\mathrm{N}$ & 63 & 63 \\
\hline & \multirow[t]{3}{*}{ Duksos } & Correlation Coefficient & $.219^{*}$ & 1.000 \\
\hline & & Sig. (1-tailed) & .042 & \\
\hline & & $\mathrm{N}$ & 63 & 63 \\
\hline
\end{tabular}

*. Correlation is significant at the 0.05 level (1-tailed).

Dengan menggunakan uji korelasi Spearman's Rho diperboleh koefesien korelasi antara dukungan sosial dengan successful aging sebesar sebesar 0.219 dengan sig sebesar $0.042(\mathrm{p}<0.05)$ yang berarti ada hubungan yang positif antara dukungan sosial dengan successful aging.

\section{Pembahasan}

Dalam penelitian ini penulis merumuskan hipotesis sebagai berikut ada hubungan positif antara dukungan sosial dengan successful aging pada lansia di Desa Bulu Kec. Argomulyo. Hasil penelitian yang diolah melalui uji korelasi Spearman's Rho menunjukan koefesien korelasi $(\mathrm{r})=0.042(\mathrm{p}<0.05)$ yang berarti ada hubungan positif antara dukungan sosial dengan successful aging pada lansia di desa bulu kec. Argomulyo. Hal ini berarti semakin tinggi dukungan sosial maka semakin tinggi pula successful aging, begitu pula sebaliknya. Dengan kata lain, variable dukungan sosial memiliki peran terhadap munculnya variable successful aging. Hasil penelitian tersebut didukung pula oleh analisis deskriptif pada tabel 1 dan tabel 2 menunjukan bahwa dukungan sosial dan successful aging pada lansia di desa bulu Kec. Argomulyo berada pada kategori tinggi.

Hubungan tersebut dapat terjadi karena lansia dengan successful aging tinggi ialah lansia yang memiliki dukungan sosial tinggi baik dalam keluarga maupun dalam masyarakat. Jika lansia yang memiliki dukungan sosial rendah maka successful aging tidak dapat terpenuhi. Pernyataan ini didukung oleh penelitian Ginting (2017), Odel (2014), dan Putri (2015) yang menyatakan bahwa terdapat hubungan yang positif antara dukungan sosial dengan successful aging.

Hubungan lansia dengan lingkungan sekitar juga sangat memengaruhi, mulai dari interaksi sosial dalam keluarga hingga lingkungan sekitar. Dengan adanya dukungan baik dari keluarga maupun lingkungan kepada lanjut usia untuk tetap melakukan segala kegiatan di lingkungannya akan membuat lansia merasa dihargai. Dalam hasil penelitian ditemukan juga bahwa r2 yang artinya pengaruh dukungan sosial terhadap successful aging sebesar $4.8 \%$ dan $95.2 \%$ dipengaruhi oleh faktor lain. 
Berdasarkan penjelasan di atas, lansia di Desa Bulu Kec. Argomulyo salatiga menunjukan bahwa kualitas hidup lansia dipengaruhi oleh beberapa faktor yang mnyebabkan seorang lansia untuk tetap bisa berguna dimasa tuanya, yakni kemampuan menyesuaikan diri dan menerima segala perubahan yang dialami, adanya penghargaan dan perlakuan yang wajar dari lingkungan lansia tersebut (Kuntjoro, 2012).

Setidaknya ada beberapa faktor yang mempengaruhi lansia dalam mencapai successful aging yakni; fisik dan kesehatan, aktifitas sosial, gaya hidup, Pendidikan dan dukungan sosial. Seseorang yang tetap aktif, baik secara fisik, mampu membina hubungan sosial dengan lingkungan secara baik, individu mampu menjaga kesehatan fisiknya dihari tua, mendapatkan dukungan untuk dirinya baik dari keluarga maupun dari lingkungan, serta dapat memposisikan dirinya dengan baik dalam menghadapi fase lanjut usianya dan terlibat aktif dalam berbagai macam aktivitas sehingga memberikan kontribusi dan kepuasaan bagi dirinya, akan membawa individu tersebut menuju usia lanjut berhasil (successful aging).

\section{PENUTUP}

\section{Kesimpulan}

Berdasarkan hasil penelitian diperoleh kesimpulan bahwa terdapat hubungan yang positif antara dukungan sosial dengan successful aging pada lansia di Desa Bulu Kec. Argomulyo. Dengan pengaruh dukungan sosial terhadap successful aging sebesaar $4.8 \%$ dan $95.2 \%$ dipengaruhi oleh faktor lain.

\section{Saran}

Berdasarkan hasil penelitian yang telah dilakukan, maka terdapat beberapa saran yang dapat diberikan penulis.

Bagi lansia yang ingin mencapai successful aging di masa tua sangat penting memperhatikan dan menjaga kesehatan fisik, kognitif, serta melakukan aktifitas sosial. Mengoptimalkan segala serta memperhatikan keseimbangan antara segala aspek, sehingga tidak condong kepada salah satu atau beberapa aspek saja. Kepada keluarga lansia diharapkan dapat meningkatkan dukungan keluarga, sehingga selau dapat mendukung para lansia untuk mencapai successful aging.

Penulis juga menyarankan agar peneliti lain dapat menggunakan teori yang sama dengan penulis gunakan dalam dua variabel tersebut. Selain itu, metode penelitian yang penulis sarankan adalah mengambil sampel di pantia wreda, sehingga dapat melihat dukungan sosial 
yang diberikan melalui lingkungan sekitar.

\section{DAFTAR PUSTAKA}

Ariani, Hamidah \& Tri Wastari. 2012. Studi Eksplorasi Successful aging Melalui Dukungan Sosial Bagi Lansia di Indonesia dan Malaysia (Skripsi) (Fakultas Psikologi Universitas Airlangga Surabaya).

Azwar, S. 2009. Penyusunan Skala Psikologi. Yogyakarta : Pustaka Pelajar.

Budiarti, R. 2010. Faktor-Faktor Successful aging. Skripsi. Universitas Muhammadiyah Malang.

Cohen, S., Hoberman, H. M. 1983. Positive events and Social Supports as Buffers Od Life Change Stress. Journal of Applied Social Psychology, 13(2).

Crowther, PhD., et all. 2002. Rowe and Khan's Model of Successful aging Revisited: Positive Spirituality-The Forgotten Factor. The Gerontologist $42(5)$; 613-620.

Ginting, Susi Astriyani Br. 2017. Gambaran Successful aging Pada Lansia Di Kecamatan Bandar Pasir Mandoge Kabupaten Asahan (Skripsi) (Universitas Sumatera Utara Repositori Institusi USU).

Hurlock, E. B. 1980. Psikologi Perkembangan: Suatu Pendekatan Sepanjang Rentang Kehidupan. Jakarta: Erlangga.

Howie, Laura Odell. 2014. Social Support And Successful aging In Assisted Living Resident. Educational Gerontology, 40: 61-70.
Khan, Robert L. 2004. Successful aging Myth Or Reality? Michigan; University of Michigan School: Social Development.

Minkler, M., \& Holstein, M. B. 2008. From Civil Rights To Civic Engagement? Concerns of two Older Critical Gerontologists About A "New Social Movement" And What It Portends. Journal of Aging Studies, 22(2), 196-204.

Papalia, D. E. \& Olds, S.W. 2009. Human Development. (11th ed.). New York: McGraw - Hill International Edition.

Putri. G. A. 2015. Hubungan Dukungan Sosial Keluarga Dengan Successful aging Pada Lanjut Usia Di Kecamatan Payakumbuh Utara kota Payakubuh. (Skripsi) (Universitas Islam Negri Sultan Syarif Kasim Riau Pekanbaru).

Rowe, J.\& Khan, R. 1997. Successful aging. New York: Phanteon Books.

Santrock, Jhon W. 2002. Life Span Development: Perkembangan masa hidup (Jil 2), Jakarta; Erlangga.

Sarafino, E. P. 1998. Health psychology: Biopsychological Interaction (4rd ed). New York: John Wiley \& Sons, Inc.

Schneiders, A. 1964. Personal Adjusment and Mental Health. New York: Brosh Publishing Company.

Sugiyono. 2009. Metode Penelitian Kuantitatif, Kualitatif dan $R \& D$. Bandung: Alfabeta.

Suardirman, S. 2011. Psikologi Usia Lanjut. Yogyakarta: Gadjah Mada University. 